\title{
8
}

\section{im

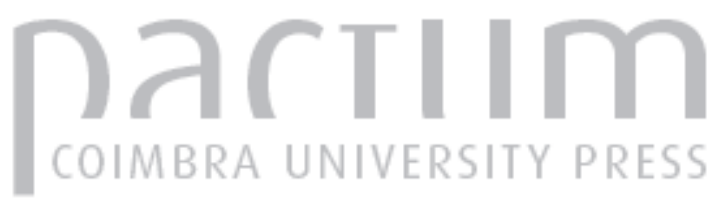

[Recensão a] A. Lima-de-Faria, Evolution without selection. Form and function by Autoevolution

Autor(es): $\quad$ Costa, António Gomes

Publicado por: Imprensa da Universidade de Coimbra

URL persistente:

http://hdl.handle.net/10316.2/42896

DOI:

https://doi.org/10.14195/2183-8925_12_20

Accessed : $\quad$ 26-Apr-2023 12:54:19

A navegação consulta e descarregamento dos títulos inseridos nas Bibliotecas Digitais UC Digitalis, UC Pombalina e UC Impactum, pressupõem a aceitação plena e sem reservas dos Termos e Condições de Uso destas Bibliotecas Digitais, disponíveis em https://digitalis.uc.pt/pt-pt/termos.

Conforme exposto nos referidos Termos e Condições de Uso, o descarregamento de títulos de acesso restrito requer uma licença válida de autorização devendo o utilizador aceder ao(s) documento(s) a partir de um endereço de IP da instituição detentora da supramencionada licença.

Ao utilizador é apenas permitido o descarregamento para uso pessoal, pelo que o emprego do(s) título(s) descarregado(s) para outro fim, designadamente comercial, carece de autorização do respetivo autor ou editor da obra.

Na medida em que todas as obras da UC Digitalis se encontram protegidas pelo Código do Direito de Autor e Direitos Conexos e demais legislação aplicável, toda a cópia, parcial ou total, deste documento, nos casos em que é legalmente admitida, deverá conter ou fazer-se acompanhar por este aviso.

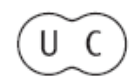




\section{UNIVERSIDADE}

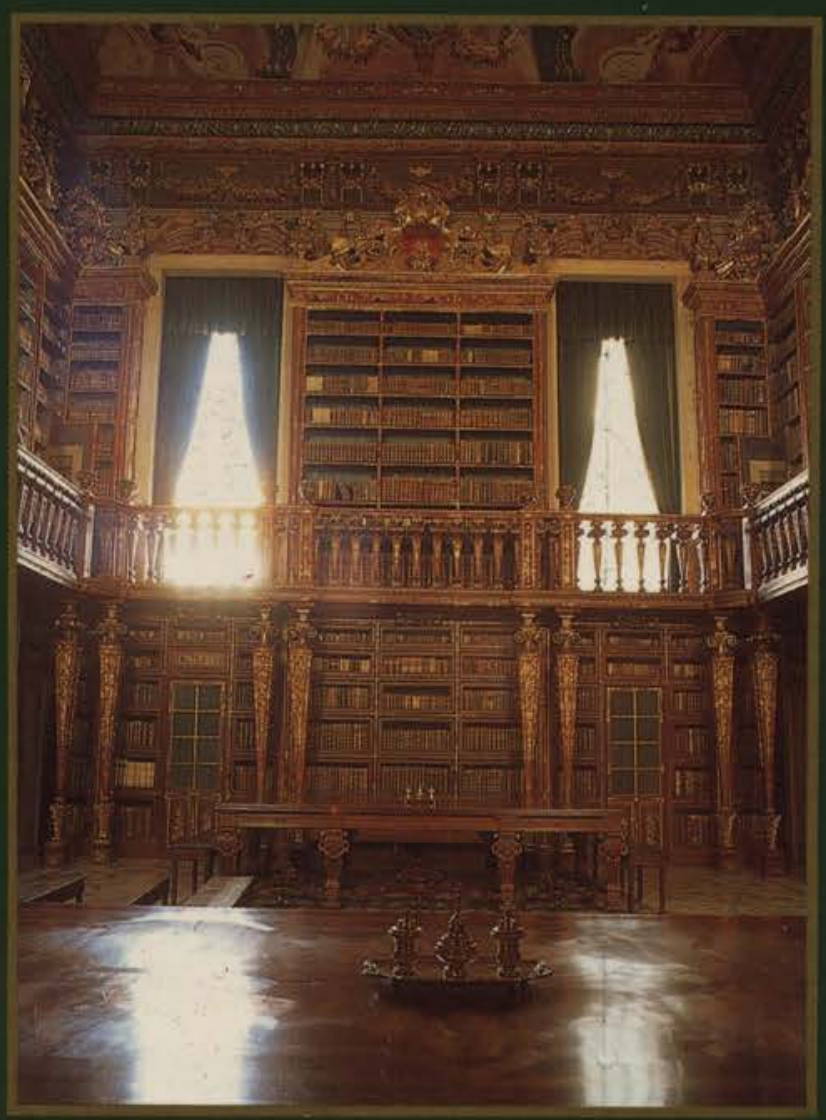

INSTITUTO DE HISTORIA E TEORIA DAS IDEIAS FACULDADE DE LETRAS 
tado na difusão dos resultados científicos através de programas diversos, desde exposições, filmes, até emissões radiofónicas, televisivas e outras. Ele tem assumido a sua quota-parte da responsabilidade da ciência face ao direito de todos os indivíduos à emancipação mental. Alguém poderá duvidar do interesse da humanidade em se libertar de dogmas e preconceitos ilusórios acerca da sua origem, das suas raízes, do seu itinerário, da sua natureza? Não se pode pôr em causa este interesse sem comprometer a natureza racional do Homo sapiens sapiens. Por outro lado, é inquestionável que a paleoantropologia e a pré-história, são as disciplinas mais aptas para demonstrar e ensinar «a densidade do tempo, a instabilidade dos seres e das coisas, a mais importante das leis da biologia, a evolução, o respeito pelo homem anterior e pelos homens de outros lugares...” (p. 201). Por isso, terminamos com uma palavra de reconhecimento dirigida a todos os cientistas que, como Yves Coppens, tomam iniciativas no sentido de corresponder às carências do público heterogéneo e lutam para que as noções de profundidade do tempo, de evolução das espécies, de origem única, tropical e leste-africana do homem, de unidade e monofiletismo do género Homo, do papel do meio, do utensílio, da sociedade, da comunicação no desenvolvimento material e espiritual da humanidade e outras noções adjacentes façam parte integrante e sejam devidamente valorizadas na educação infantil e juvenil. Ao procederem deste modo, eles estão, de facto, a difundir resultados científicos que reforçam e fundamentam o ideal da paz e da fraternidade entre todos os povos, culturas e civilizações. Neste sentido, merece ser invocada a exposição «Origens do homem» que Yves Coppens realizou no Museu do Homem em 1976. Do seu impacte pedagógico falam os 6.000 comentários que os visitantes produziram ao verem a sua imagem reflectida num espelho - a sua própria pessoa como último elo de uma cadeia de 70 milhões de anos de história.

\section{Ana Leonor Pereira Dwarkasing}

A. Lima-de-Faria, Evolution without selection. Form and Function by Autoevolution, Amsterdam, (New York, Oxford), Elsevier, 1988. Auto-evolução: uma revolução científica ou a subversão da ciência?

O Professor António Lima-de-Faria é licenciado em Ciências Biológicas pela Universidade de Lisboa e doutorado em Genética pela Universidade de Lund, Suécia, onde é presentemente Professor Catedrático. Desenvolveu um trabalho considerável dentro do campo da genética, tendo vários artigos e livros publicados sobre o assunto. Neste seu úl- 
timo livro pretende demonstrar que a teoria da evolução, genericamente designada por neo-Darwinismo, está profundamente errada; além disso, propõe as bases para uma nova teoria explicativa da evolução: a autoevolução. A divulgação deste livro tem sido acompanhada por conferências realizadas pelo autor através da Europa, no âmbito das quais veio a Coimbra, de 16 a 18 de Maio de 1989.

A presente obra divide-se em sete seç̧ões principais, subdivididas

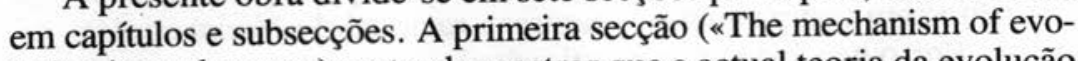
lution is not known") pretende mostrar que a actual teoria da evolução nada explica. Nas quatro secções seguintes («The three evolutions that preceeded and canalized biological evolution», «Self-assembly is the visible consequence of autoevolution", "Counteraction of de original construction" e "The changes imposed by the environment») o autor relaciona vários factos experimentais e observações e lança as bases da autoevolução. Na sexta secção («Elucidation of the 'puzzling facts' of evolution by autoevolutionism») a autoevolução é aplicada para explicar aquilo que o autor acha serem aspectos enigmáticos da evolução e estende o autoevolucionismo à sociobiologia. Na última secção («Towards an experimental period in evolution») é feito um apelo para que certos conceitos científicos, nomeadamente no campo da física, sejam revistos; além disso, são sumarizados os diferentes princípios da autoevolução, após o que se segue uma comparação exaustiva entre a autoevolução e o neo-Darwinismo.

Ao longo de todo o livro encontramos um conjunto impressionante de factos e observações científicas que constituem, sem dúvida, o resultado de um trabalho exaustivo de consulta e que vão desde a constituição das partículas elementares até às interacções sociais nos animais e no homem, passando por vários campos diversificados do conhecimento humano: mecânica quântica e clássica, termodinâmica, mineralogia, cristalografia e física do estado sólido, genética molecular, fisiologia, taxonomia, bioquímica, química orgânica e inorgânica, química física, evolução, anatomia, sociobiologia, sociologia e, ainda, história das ciências, entre outros. Todos estes factos estão bem documentados e muitos deles são bem conhecidos, constituindo aspectos fundamentais das várias ciências em questão.

Qualquer texto que pretenda ser científico, que critique uma teoria científica e que proponha uma nova teoria deve, em princípio, obedecer a alguns critérios básicos: apresentar correctamente ao leitor os vários aspectos da ciência que nele são abordados, fundamentar convenientemente a(s) crítica(s) que faz e, se pretende apresentar uma nova teoria, esta deve ser clara e fornecer, senão a explicação completa, pelo menos pistas para a compreensão de factos observados.

Infelizmente, o livro do Professor Lima-de-Faria não respeita nenhum destes critérios. 


\section{Deturpação da ciência}

Durante todo o livro, a estratégia de apresentação científica adoptada pelo autor consiste na descrição de observações ou factos isolados, aparentemente sem relação entre si ou, pelo menos, supostamente não relacionados nem integrados pela ciência actual. Aquilo que nos fica da leitura da obra é a noção de que, pela primeira vez, se entra em consideração com as propriedades dos elementos químicos e com as leis físicas para descrever a vida, que pela primeira vez se relacionam os minerais e processos de cristalização com os seres vivos, que a interacção entre forma e função é um conceito novo, e assim por diante. Isto não é verdade. Posso, sem qualquer dúvida, afirmar que todos os factos apresentados pelo autor podem ser (e são) coerentemente integrados e tentativamente explicados pela ciência actual. É grave que essa explicação seja sonegada ao leitor. E, mais grave ainda, é o facto de esta estratégia de apresentação de factos isolados e não relacionados conduzir necessariamente a uma imagem errada da ciência, pois esta não é, de modo nenhum, apenas um conjunto de factos empíricos inarticulados.

Consideremos um exemplo: o autor escreve uma secção em que fala sobre o papel do cálcio nos seres vivos; depois de enumerar abreviadamente as funções deste ião nas plantas, prossegue: «nos animais, os iões de cálcio controlam processos que vão desde a contracção muscular até à divisão celular. Proteínas especializadas em ligar cálcio regulam a sua concentração na célula e os efeitos por ele mediados. Assim, não é um gene, não é uma macromolécula, nem sequer uma pequena molécula, mas apenas um componente tão simples como o ião cálcio que é o principal componente no controlo destes processos. Isto acontece porque o cálcio funciona como segundo mensageiro na comunicação intracelular» (p. 71-72); Nada mais é explicado e não há qualquer tentativa de integrar estas observações no conjunto lógico da biologia, passando a ser descrito outro aspecto sem interligação imediata. A penúltima frase (o sublinhado é meu) induz o leitor a ter uma imagem errada da biologia. Esta e outras observações semelhantes ao longo do livro, levam a concluir que a biologia não integra o papel de iões em todos os processos vitais, que os biólogos ignoram os fundamentos físicos e químicos básicos que são responsáveis por vários aspectos fisiológicos e morfológicos e que se pensa que tudo é controlado por genes e macromoléculas de um modo estranho e particular aos seres vivos; esta impressão é acentuada por frases díspares e espalhadas ao longo da obra (por exemplo: «as bolas de sabão não têm genes e, no entanto, reproduzem os padrões encontrados durante a divisão celular nos ovos" (p. 130).

Não posso aqui explicar toda a biologia, mas posso afirmar que 
o grande avanço desta ciência se deve exactamente à premissa de que tudo pode e deve ser explicado em termos simples de leis físicas e químicas: hoje em dia, entende-se o impulso nervoso como um fenómeno electroquímico devido a gradientes iónicos, as membranas biológicas explicam-se como sendo o resultado da associação espontânea de moléculas de modo a formar cristais líquidos (esta associação espontânea não tem nada de misterioso e deve-se às mesmas atracções e repulsões físicas que levam o azeite a separar-se da água e as bolas de sabão agregadas a adoptarem o padrão dum ovo em divisão), estuda-se a alteração de ligações atómicas que ocorrem em receptores de hormonas e sintetizam-se genes com técnicas químicas simples. E, que a interdisciplinaridade e integração dos vários ramos das ciências constitui uma prática frutuosa a que a biologia tem recorrido para o seu desenvolvimento, é algo que está bem patente nas designações de diferentes áreas de estudo: biofísica, bioquímica, biologia molecular, etc.

É particularmente grave (para mais sendo o autor um geneticista molecular) a noção transmitida de que os biólogos consideram que os genes controlam tudo nos organismos vivos. Desde que se identificou uma base molecular para a hereditariedade que o gene deixou de ser considerado uma entidade mística e omnipotente. A sua acção está perfeitamente determinada e é também explicada por mecanismos físicos e químicos simples. Há muito que o seu papel na determinação das características de um organismo é considerado como sendo sem dúvida importante, mas limitado.

\section{2. «Autoevolução» - um conceito tautológico}

Tanto quanto se pode entender pela leitura deste livro, o conceito de autoevolução baseia-se num conjunto de observações que conduzem à seguinte conclusão: desde os átomos às moléculas, dos cristais aos seres vivos, os princípios ou leis básicas que regulam as suas formas e funções são os mesmos. Esta conclusão, como afirmei anteriormente, é um facto básico aceite pela ciência desde os seus primórdios, ou, melhor, é um facto que foi concluído pela ciência. Pode mesmo afirmar-se, correndo o risco de ser reducionista, que esta observação emerge constantemente da prática científica e que o motor básico de todas as ciências exactas tem sido a explicação de como um conjunto simples de leis produz o mundo aparentemente diverso que conhecemos.

Como referi, Lima-de-Faria limita-se a apresentar dados soltos e, recusando recorrer ao corpo actual da ciência para integrar e explicar o enorme conjunto de factos e observações expostos no livro, propõe um conceito novo, a autoevolução. Logo na página 18, dá-nos a definição de autoevolução e de autoevolucionismo: «Devo confessar que tenho uma certa aversão a criar novas palavras. No entanto, neste ca- 
so, senti-me forçado a inventar a palavra autoevolução. Ela descreve o fenómeno de transformação que é inerente à construção da matéria e da energia. Consequentemente, isto produziu e canalizou a transformação dos sistemas biológicos. Â interpretação deste fenómeno, proposta nas páginas seguintes, chama-se autoevolucionismo. Logo adiante, continua: «A consequência directa da autoevolução tem sido o aparecimento de formas e funções que foram todas derivadas e moldadas pelas propriedades iniciais da matéria e energia». Assim, embora não se chegue a entender o que é a autoevolução, a não ser como um "princípio" abstracto inerente à matéria e energia, o autor propõe uma consequência directa desse mesmo princípio.

Durante o resto do livro, pouco mais é explicado sobre o que é, concretamente, a autoevolução, e as restantes observações que aparecem como elucidativas ou exploratórias do conceito pouco adiantam à sua compreensão: "A evolução da matéria é considerada como tendo começado com total simetria e como tendo mudado sucessivamente para graus diferentes de assimetria. Isto leva-me a considerar as seguintes relações: de um lado colocamos o que podem ser chamados os estatutos de energia ultra-elevada: simetria, matéria e forma. No lado antitéctico: assimetria, energia e função (...). Cada lado é convertível a sua contraparte antitética». (p. 45). Aonde o autor pretende chegar com estas relações é manifesto noutro capítulo: após descrever as experiências de Pasteur com cristais levógiros e dextrógiros (cristais da mesma substância mas que diferem entre si porque rodam a luz polarizada em direcções opostas) e após fornecer mais exemplos da importância da existência de moléculas com conformações espaciais opostas, Lima-de-Faria conclui: «Esta evidência leva-me a postular que a assimetria cria a função enquanto que a simetria cria a forma. Por outras palavras, quando um fenómeno está no seu estado simétrico ele aparece como forma; quando o mesmo fenómeno está numa condição assimétrica ele aparece como função» (p. 86).

São estas as «leis" propostas pelo autor para que entendamos o mundo que nos rodeia.

Um exemplo de aplicação da autoevolução para explicar um facto observado encontra-se na página 110 , a propósito das semelhanças notáveis que existem entre certos insectos e folhas de plantas (aliás, este é o único exemplo concreto de uma tentativa de explicação «autoevolucionista» em toda a obra): «Todas estas parecenças resultam de uma construção atómica e molecular semelhante. A simetria é uma característica básica da organização das plantas bem como da dos corpos e órgãos dos animais. (...) $\mathrm{O}$ insecto, como outros animais, contém no seu genoma um certo número de genes que foram herdados de plantas ancestrais. Isto ocorreu antes de as plantas e animais se separarem milhares de anos atrás. Alguns destes genes podem não ser usualmente 
expressos no insecto, onde foram suplantados por genes característicos do fenótipo animal. No entanto, por certas vias moleculares, a ancestralidade mineral, conjuntamente com alguns genes ancestrais de plantas, pode dar origem a um padrão de folha. O inesperado e súbito resultado é um insecto que parece uma folha».

Este exemplo é paradigmático de todo o livro: nada fica, de facto, esclarecido sobre o mecanismo que levou a que um insecto se pareça com uma folha, exceptuando uma noção vaga de "vias moleculares" misteriosas e de "ancestralidade mineral e vegetal»; os conceitos de autoevolução enunciados em nada ajudam a clarificar o problema; por último, o leitor fica no desconhecimento total de que a ciência tem actualmente conhecimentos muito concretos que podem ser elaborados de modo a fornecer uma explicação muito mais clara da origem deste insecto.

Assim, a autoevolução aparece-nos, não como um conceito construído dentro da ciência, mas, antes, como um conceito elaborado à margem da ciência. É um conceito quase metafísico, pouco claro e que em nada ajuda a compreender os factos expostos. E um conceito tautológico, que só explica a ele próprio: a autoevolução é «um fenómeno de transformação que é inerente à construção da matéria e energia” e, assim, as transformações da matéria e energia observadas explicam-se pela autoevolução.

Pedir ao leitor que esqueça teorias bem fundamentadas e as substitua pela autoevolução é pedir demasiado.

\section{Crítica ao Darwinismo - afirmações incorrectas}

Quer pelo título, quer pelos capítulos iniciais da obra, este livro constituiu-se num ataque violento à teoria de evolução Darwiniana.

O mínimo que se pode pedir a um cientista que pretende eliminar uma teoria científica é que forneça informações correctas sobre os postulados e consequências dessa teoria. É, portanto, inadmissível que Lima-de-Faria, ao longo de todo o livro, apresente uma série de noções complementares erradas sobre o que é a selecção natural e o Darwinismo.

Além de nunca ser explicado ao leitor o que é a teoria da evolução Darwiniana, encontram-se frequentemente afirmações não fundamentadas: «Para o Darwinismo e neo-Darwinismo, a variação é o componente principal da evolução. A constância de formas e funções são vistas como pertencendo à hereditariedade. É por isto que o conceito de hereditariedade foi criado como uma noção separada da de evolução. Para além disto, considera-se que a variação ocorre ao acaso e em todas as direcções possíveis» (p. 31). Afirmações deste tipo representam um conjunto grave de deturpações da realidade: a primeira frase é extre- 
mamente reducionista; além disso, a hereditariedade está tão integrada no conceito de evolução que este aparece e aperfeiçoa-se exactamente através dos estudos de mecanismos hereditários; finalmente, não são, de modo algum, as variações que ocorrem "ao acaso e em todas as direcções possíveis", mas as mutações genéticas (e esta é uma distinção fundamental em toda a teoria Darwiniana).

O autor aponta como algo que «criou a crise e precipitou a queda do neo-Darwinismo" o facto de "os genes não mudaram permanentemente, como era considerado previamente, mas muitos genes têm sido preservados essencialmente sem modificações, das bactérias aos seres humanos" (p. 14). Há, de facto, vários genes que se dizem ser "conservados"; porque são muito idênticos em todos os organismos. Normalmente, estes genes codificam proteínas fundamentais para a sobrevivência de um ser vivo, ou seja, pequenas alterações no gene levam a modificações na estrutura da proteína que implicam a sua não-funcionalidade; qualquer indivíduo que sofra uma mutação no gene não será viável e morrerá, não deixando por isso descendência que transporte a mutação; assim, só os indivíduos com o gene intacto é que permanecem vivos e têm descendência. É, deste modo, fácil de compreender que esse tipo de genes permaneça imutável ao longo da evolução. $\mathrm{O}$ mecanismo de preservação genética que acabei de expor chama-se selecção natural e as suas bases foram lançadas por Darwin.

Em outro ponto, o autor afirma que os agentes físicos, como a gravidade, electricidade e magnetismo não têm sido considerados como agentes motores da evolução e que estes factores «são considerados como pertencendo apenas ao campo da fisiologia e não são reconhecidos como os mecanismos básicos que dirigiram a evolução» (p. 49). Suponho, no entanto, que não seja preciso explicar ao leitor que a fisiologia e a morfologia são interdependentes e que a sua evolução está relacionada; que quando se discute a evolução das aves e a forma das asas se tem que entrar em consideração com a influência da gravidade, que se considera o campo magnético terrestre como um dos factores que moldou toda a história evolutiva, que se demonstra que os insectos são todos pequenos devido a uma relação física simples entre o aumento de volume e o aumento do peso correspondente (que tornaria impossível a sustentação de insectos grandes por um exoesqueleto), que não há peixes cúbicos por uma questão de hidrodinâmica, em suma, que toda a história da evolução e todo o Darwinismo tem que ter forçosamente em atenção as leis da física e os agentes físicos a que os organismos vivos estão submetidos.

Lima-de-Faria dedica uma secção inteira à não existência de monstros que, segundo ele, seriam produzidos forçosamente por uma evolução com base em mutações aleatóreas (pp. 35-36) e afirma que, ao longo das eras geológicas, a evolução apenas produziu formas harmo- 
niosas, facto que, segundo o autor, não pode ser explicado pela selecção natural. Não é, no entanto, difícil de compreender que a noção de «harmonia» é um conceito a posteriori, que tudo o que existe nos parece correcto e que, se possuíssemos um olho e dois narizes isso seria considerado harmonioso. Assim, a noção de «monstro» implica exactamente algo que não existe. É simplesmente por isto que um processo evolutivo, qualquer que ele seja, não pode dar origem a monstros.

Vários outros exemplos poderiam ser dados sobre a profunda incorrecção dos ataques que Lima-de-Faria faz ao Darwinismo, mas vou apenas citar mais um: na página 281, encontramos a seguinte frase: «A ortodoxia dos neo-Darwinistas leva-os a extremos" [como exemplo desta ortodoxia, cita uma frase de Owen]: «A resina é produzida pelos pinheiros com a finalidade de impedir que os insectos se alimentem deles». Neste ponto, o autor critica os Darwinistas contrapondo que, no entanto, "nada tem uma intenção na natureza». Assim, Lima-de-Faria afirma implicitamente que o Darwinismo e a selecção natural se constituem num mecanismo de evolução dirigida, intencional e com uma finalidade óbvia. Nada pode ser tão falso, pois a ideia-base de todo o Darwinismo é, exactamente, a de que «nada tem uma intenção na natureza». Foi essa a grande batalha que Darwin travou no seu tempo, a de fazer implantar uma teoria da evolução não determinada pelos conceitos de necessidade e finalidade, em oposição a outras teorias, como as propostas por Lamarck (a frase de Owen citada pelo autor não é um exemplo único e todos nós caímos em discursos antropocêntricos de intencionalidade por uma questão de facilidade de raciocínio).

Lima-de-Faria refere ainda as diferentes interpretações Darwinianas da evolução, mostrando como os vários autores «Darwinianos» discordam entre si na explicação de muitos factos. Quanto a mim, isto apenas mostra o que acontece em qualquer área do conhecimento que não tenha sido considerada obsoleta, e representa o processo universal de construção da ciência. É salutar que a preocupação de responder a problemas seja igualada por uma preocupação em levantar questões.

Ser Darwinista não é a afirmação da detenção da verdade última que explica o mundo vivo actual. E, antes, a aceitação de um conjunto de factos que resultam na formulação coerente de uma hipótese; esta hipótese gera muitas respostas e, ao mesmo tempo, provoca interrogações prementes e discussão. Como em todos os outros campos da ciência, isto conduzirá, não a uma resposta final e absoluta, mas à formulação frutífera de mais questões.

Na minha opinião, o livro em causa, encarado como o resultado de uma análise científica e proponente de uma nova teoria não faz qualquer sentido. A única questão que este livro me levanta é a seguinte: que mecanismos de validação social e científica permitem que Lima- 
-de-Faria publique o livro numa editora conceituada e realize conferências amplamente publicitadas e implicitamente apoiadas pelos seus pares? Deste ponto de vista, o livro pode ter interesse enquanto objecto de análise.

Logo na introdução, o autor avisa que «alguns dos meus colegas podem achar este livro demasiadamente provocador» e diz ainda que «o Darwinismo é algo que aprendemos em muito novos e tem sido martelado nas nossas mentes como sendo um truísmo. Os psicólogos sabem bem como é difícil apagar, ou mesmo apenas substituir, ideias adquiridas tão cedo" (p. xxi). Assim, ao criticar o presente livro, coloco-me na situação potencial de conservador. Antes e depois da sua leitura, continuo a achar que o neo-Darwinismo é uma boa teoria. Não sou um «adepto» do neo-Darwinismo, porque aqui não se trata de uma questão de fé, mas considero que o neo-Darwinismo constitui um conjunto articulado de factos e ideias que, até ao presente momento, oferece a melhor explicação da evolução e diversidade da vida.

No entanto, a crítica que faço ao presente livro não é restrita a esta questão. É enquanto biólogo, em particular, e cientista no geral, que considero que as leis nele apresentadas constituem um absurdo.

Ao longo do seu livro o autor não põe só em causa a teoria da selecção natural. Entre outras coisas, faz uma releitura do princípio de incerteza de Heisenberg (p. 299), considera a mineralogia uma ciência atrasada (p. 75), diz em vários sítios que o acaso na física e na biologia é um sinónimo de ignorância (p. 32 e outras) pretende destruir a validade da nova lei da termodinâmica (p. 302). No fim do livro, descreve um capítulo intitulado «Não é a biologia que deve ser mudada, mas sim a física».

Em suma, Lima-de-Faria põe em causa todo o edifício científico. Em troca, nada nos propõe senão a noção de que o universo observável possui características constantes, desde os minerais aos seres vivos, sendo isso um facto que deve ter um significado que, segundo $o$ autor, não é considerado pela ciência actual. Afirmar isto representa regressar ao obscurantismo e misticismo que antecederam a construção racional de todo o universo científico.

\section{António Gomes da Costa}

William J. Callaham, Iglesia, poder y sociedad em España, 1750-1874, Madrid, Editorial Nerea, 1989, 314 p.

A obra do historiador canadiano William J. Callaham, editada em língua inglesa no ano de 1984 e recentemente publicada em Espanha, parece-nos essencial para a compreensão da realidade político- 